\title{
Downward mobility and Rawlsian justice
}

\author{
Govind Persad ${ }^{1}$
}

(C) Springer Science+Business Media Dordrecht 2017

\begin{abstract}
Technological and societal changes have made downward social and economic mobility a pressing issue in real-world politics. This article argues that a Rawlsian society would not provide any special protection against downward mobility, and would act rightly in declining to provide such protection. Special treatment for the downwardly mobile can be grounded neither in Rawls's core principles - the basic liberties, fair equality of opportunity, and the difference principle-nor in other aspects of Rawls's theory (the concept of legitimate expectations, the idea of a life plan, the distinction between allocative and distributive justice, or the distinction between ideal and nonideal theory). Instead, a Rawlsian society is willing to sacrifice particular individuals' ambitions and plans for the achievement of justice, and offers those who lose out from justified change no special solicitude over and above the general solicitude extended to all. Rather than guaranteeing the maintenance of any particular individual or group's economic position, it provides all of its members - the upwardly mobile, the downwardly mobile, and the immobile — a form of security that is at once more generous and more limited: that they will receive the liberties, opportunities, and resources promised by the principles of justice.
\end{abstract}

Keywords Social mobility · Economic mobility · Legitimate expectations · Trade $\cdot$ Automation $\cdot$ Social change $\cdot$ John Rawls

Changes in labor, housing, and other markets have brought concerns about downward social and economic mobility to the forefront of political debates.

Govind Persad

gpersad@jhu.edu

1 Berman Institute of Bioethics, Johns Hopkins University, 1809 Ashland Ave., Baltimore, MD 21205, USA 
Globalized economic competition and labor mobility has disrupted stable social and economic positions, as has technical innovation such as the automation of tasks and the easy dissemination of digital content. However, the threat that change poses to those currently occupying these formerly stable but now precarious positions is frequently not absolute deprivation, but rather relative deprivation-and, in particular, deprivation relative not to others wealth, but rather to their own past standard of living.

In this article, I argue that a broadly Rawlsian society would not provide downwardly mobile individuals with any special protection against, or compensation for, the effects of social change, and that it would act rightly in not providing such protection. Rather, all members of a Rawlsian society would enjoy a secure guarantee of basic liberties, a decent social minimum, and fair opportunity to compete for positions of advantage. As an exegetical matter, Rawls's theory offers no special assistance to those who suffer the effects of downward mobility. As a normative matter, its lack of special solicitude for the downwardly mobile is desirable and not regrettable.

Rawls's most direct discussion of downward mobility occurs in a brief comment on free trade:

Persons engaged in a particular industry often find that free trade is contrary to their interests. Perhaps the industry cannot remain prosperous without tariffs or other restrictions. But if free trade is desirable from the point of view of equal citizens or of the least advantaged, it is justified even though more specific interests temporarily suffer. For we are to agree in advance to the principles of justice and their consistent application from the standpoint of certain positions. There is no way to guarantee the protection of every interest over each period of time once the situation of representative men is defined more narrowly. Having acknowledged certain principles and a certain way of applying them, we are bound to accept the consequences. This does not mean, of course, that the rigors of free trade should be allowed to go unchecked. But the arrangements for softening them are to be considered from an appropriately general perspective. ${ }^{1}$

Free trade may be "desirable from the point of view of equal citizens or of the least advantaged" because it permits workers to specialize in their most productive occupation, or drives down the cost of producing consumer goods, such as clothing, needed by all but especially by the disadvantaged. Other policy changes, as well as technical innovation, might be similarly desirable despite their disruptive effects on specific groups or industries. Policy changes such as carbon taxes or farm subsidy reforms enable society to avoid the worst effects of climate change or improve access to healthy foods. Technological advances like the Internet and the cellular phone enable individuals to more easily communicate with loved ones and bring products to market.

\footnotetext{
1 John Rawls, A Theory of Justice (Cambridge: Harvard University Press, 1999), p. 85.
} 
Yet, as Rawls observes, changes desirable from the point of view of justice frequently impose losses on particular individuals or groups. Carbon taxes may hurt coal miners. Entrepreneurs may wreak creative destruction on established firms. Trade liberalization may render assembly-line manufacturing obsolete in developed nations. Rawls recognizes the possibility that changes consistent with justice may disadvantage specific groups not only in his brief discussion of free trade, but also in his longer examination of efficiency and justice, where he observes that even if several arrangements are equally efficient - in the sense that moving from one efficient arrangement to another will always worsen the prospects of some groupwe may select a more just arrangement at the expense of a particular individual or group's prospects.

To illustrate the potential breadth of downward mobility, consider six cases where economic or social changes produce downward mobility:

1) Gasoline Taxes. The threat of climate change leads to substantially higher gasoline taxes. These taxes cause homes in exurban areas to lose much of their value; many homeowners in these areas face the prospect of needing to move, losing much of their home equity, or even foreclosure.

2) Physician Payments. National health insurance leads to reduced payments to physicians. While those who expected to be physicians can still earn a decent living practicing medicine, their living standards are substantially reduced from what they expected.

3) Free Market Ethanol. Cheaper, more efficient sugarcane ethanol is imported from Brazil to the United States, because tariffs have been eliminated, and replaces corn-based ethanol. This lowers gasoline prices and creates jobs in the importing industry, but destroys the jobs of farmers and corn-based ethanol producers.

4) Automated Trucking. Automated vehicles are deployed in the trucking industry and, because of their improved safety and efficiency, largely displace human truck drivers. Former truck drivers must retrain or face income declines.

5) Gourmet Trends. Popular culture extols the virtues of cuisines that feature fresh vegetables and herbs. Sales of canned vegetables and precooked meals drop, and both stockholders and employees suffer economic losses.

6) Inflation. To stimulate broader economic growth and reduce unemployment, the Federal Reserve increases the money supply, leading to higher levels of inflation. This inflation reduces the purchasing power of those holding wealth.

The first three cases build on the work of theorists-Lukas Meyer, Nien-hê Hsieh, and Aaron James-who argue in favor of special protections against downward mobility, while the final three develop similar ideas in different directions. Meyer argues that "the expectation of people in the highly industrialized countries... that they will be able to emit on average what collectively will amount to their states' current level of emissions and up to that level in the future" is politically, morally, and epistemically legitimate, and that their expectations constrain efforts to combat 
climate change. ${ }^{2}$ Hsieh argues that we must respect doctors' "legitimate expectations" of earning a pre-reform market wage. ${ }^{3}$ And James asserts that "because it seems unfair to worsen someone's condition by $\$ 1000$ merely to give someone else $\$ 1500$," relaxing a tariff when doing so will drive down the wages of some domestic workers requires a weighty justification. ${ }^{4}$

These cases illustrate that downward mobility encompasses a variety of different economic causes and effects: it can include loss of firms' capital (INFLATION); of homeowners' wealth (Gasoline TaXes); or of labor income (Physician Payments, Free Market Ethanol, Automated Trucking). And it can stem from technical innovation (Automated Trucking), consumer preferences (Gourmet Trends), legal reform (Inflation, Free Market Ethanol, Physician Payments), or a combination of law with natural phenomena (GASOLInE TAXES).

Downward mobility's implications also cut in complex ways across political classifications. For instance, thinkers on the right might argue that we must compensate or protect the losers in Inflation, but not in Automated Trucking; meanwhile, many on the left would advocate for the reverse. In contrast, I argue that they are all amenable to the same analysis. I see no decisive reason to be more concerned about changes that policymakers bring about than those they fail to prevent, changes resulting from trade rather than technical innovation or shifting consumer preferences, or changes threatening income rather than wealth (or vice versa). Similarly, I reject Hayek's well-known suggestion that the effects of a spontaneous market order on individuals — as in GouRMET TRENDS — are outside the scope of justice. ${ }^{5}$ Our ability to limit the effects of a "spontaneous" market order by compensating the losers in Gourmet TRENDs entails that whether or not to compensate them is a question of justice, rather than a question outside justice. This view about the broad scope of justice finds additional support in the fact that the major political and social institutions of a Rawlsian society include the market and family as well as the state. Therefore, while I agree with Hayek's conclusion that we should not compensate the losers in GoURMET TRENDS, my agreement stems not from a belief that the market's results are uncriticizable but instead from the belief that merely suffering an economic setback-whether due to the market, nature, or just laws, and whether the setback constitutes lost income or lost wealth-does not, without more, generate an entitlement to aid at public expense.

While Rawls, like Meyer, Hsieh, and James, recognized the burdens that institutional change can place on individuals and industries, his conclusions about what we should do to ease those burdens diverge from theirs. In the next two sections, I consider and argue against interpretations of Rawls's theory of justice that would justify special protections against downward mobility. I first consider

\footnotetext{
${ }^{2}$ Lukas H. Meyer and Pranay Sanklecha, "Individual Expectations and Climate Justice," Analyse \& Kritik 2 (2011): 449-471, at p. 468.

3 Nien-hê Hsieh, "Moral Desert, Fairness and Legitimate Expectations in the Market," Journal of Political Philosophy 8 (2000): 91-114, at p. 103.

4 Aaron James, Fairness in Practice (New York: Oxford University Press, 2012), p. 207.

5 See F.A. Hayek, Law, Legislation, and Liberty, vol. 2: The Mirage of Social Justice (Chicago: University of Chicago Press, 1976), p. 33.
} 
whether special measures for the downwardly mobile could be grounded in Rawls's principles of justice:

(a) The basic liberties

(b) Fair equality of opportunity

(c) The difference principle

I argue that none of these require special treatment for those experiencing downward mobility. Rather, they recommend providing a more general form of protection to all members of society.

I then consider whether other aspects of Rawls's theory might support special treatment for the downwardly mobile where his core principles do not. These include:

(d) The concept of legitimate expectations

(e) The idea of a life plan

(f) The distinction between allocative and distributive justice

(I cover these potential sources for special treatment in descending order of their plausibility.) I argue that these concepts either do not support special measures for the downwardly mobile or are subordinate to the principles of justice. Last, although my focus is primarily on how Rawlsian ideal theory would approach downward mobility, I close with a discussion of how the distinction between ideal and nonideal theory might bear on questions concerning downward mobility.

Ultimately, although Rawlsian justice lacks a separate and distinct theoretical framework for approaching problems of institutional change, ${ }^{6}$ it offers a very simple and normatively attractive way of addressing institutional change: offer those who lose out from justified change no special solicitude over and above the general solicitude extended to all. All members of a Rawlsian society, including those who lose from social change, those who gain, and those who never had much to lose in the first place, enjoy the same social guarantees: the basic liberties, fair equality of opportunity, and the difference principle. A Rawlsian society does not guarantee the maintenance of any particular individual or group's economic position. Rather, it provides all of its members - the upwardly mobile, the downwardly mobile, and the immobile - a basic structure in which they can lead a fulfilling and vibrant life. While a Rawlsian society is willing to sacrifice the details of particular individuals' ambitions and plans to the achievement of justice, it provides individuals a guarantee against being deprived of social goods or arbitrarily controlled by the powerful.

This conclusion is particularly interesting because it suggests that an influential strand of thought in analytic political philosophy-Rawls's theory of distributive justice_-provides an important insight into how to respond to social change. Some have recently suggested that Rawls's theory of justice provides us a framework for

\footnotetext{
6 Allen Buchanan, "Distributive Justice and Legitimate Expectations," Philosophical Studies 28 (1975): 419-425, at p. 425.
} 
responding to the growth of real-world inequality. ${ }^{7}$ I believe Rawls's theory is likewise relevant to currently pressing political questions surrounding downward mobility. And my examination of Rawls's theory suggests that it has implications that are more revisionary for these questions than it might initially seem.

\section{Downward mobility and Rawlsian principles}

Rawls's theory of justice involves two principles, which are presented in order of priority. The first principle is that each individual is entitled to a set of basic liberties that is compatible with equal liberties for others. The second principle is that inequalities in social and economic circumstances, for example higher pay for workers in certain jobs, must be attached to positions that are substantively open to all (fair equality of opportunity) and must be to the greatest benefit of the worst-off group in society (the difference principle). In what follows, I separate the second principle into its two parts, which Rawls also presents in order of priority.

\subsection{The basic liberties}

Downward mobility would clearly be objectionable were it to deprive individuals of their most fundamental entitlement-their basic liberties. But it poses, in itself, no threat to most basic liberties. Only if it leads to absolute deprivation will it threaten political rights, liberty of conscience, and physical integrity. The only basic liberty that dropping from, say, the upper middle to the working class might threaten is the "right to hold personal property and freedom from arbitrary arrest and seizure as defined by the concept of the rule of law." ${ }^{8}$ However, downward mobility does not violate the rule of law. Nor does it deprive individuals of protected personal property.

\subsubsection{The rule of law}

Alexander Brown argues that the rule of law "requires that public bodies manage changes in ways that respect the legitimate expectations of those adversely affected." 9 Because the rule of law is a basic liberty, lexically subordinate principles such as fair equality of opportunity or the difference principle cannot be realized at its expense. On this interpretation, therefore, legitimate expectations would constrain distributive and egalitarian goals.

\footnotetext{
7 Joshua Cohen (with Seth Resler), "Occupation as Fairness: What John Rawls Would Make of the Occupy Movement," Boston Review (Nov. 17, 2011), http://bostonreview.net/joshua-cohen-seth-reslerjohn-rawls-occupy-wall-street; Steven Mazie, "Rawls on Wall Street," The New York Times (Oct. 21, 2011), http://opinionator.blogs.nytimes.com/2011/10/21/rawls-on-wall-street/.

${ }^{8}$ Rawls, A Theory of Justice, p. 53.

9 Alexander Brown, "Rawls, Buchanan, and the Legal Doctrine of Legitimate Expectations," Social Theory and Practice 38 (2012): 617-644, at p. 634.
} 
Brown's understanding of the rule of law runs contrary to Rawls's. As Brown himself concedes, Rawls's definition of the rule of law comprises only a few basic ideas, namely

the precept that ought implies can; the precept that similar cases be treated similarly; the precept that there is no offense without law; [and] the precepts of natural justice, including the precept that there is due process in law. ${ }^{10}$

Importantly, this list excludes substantive protection for expectations. Given the limitations that an overexpansive understanding of the rule of law would place on efforts to realize the difference and equality of opportunity principles, this exclusion was no oversight. Further, the descriptive fact that some nations' legal cultures explicitly protect substantive expectations does not provide decisive reason either to read Rawls as defining the rule of law to protect expectations or to treat such protection as normatively justified or required. ${ }^{11}$

Ellen Frankel Paul likewise argues that rule of law considerations require that the protection of individuals' expectations trump fair equality of opportunity and the difference principle. She argues that

[a]n explicit component of the first principle of justice, that which decrees equal compatible liberties for all, is the traditional notion of the rule of law which dictates in part: (1) that laws be enacted in good faith and that this good faith be recognized by those subject to the enactments; (2) that similar cases be treated similarly, and (3) that laws ought not be retroactive. Rawls terms this "justice as regularity," and he concludes that the rules of a legal system ought to serve to organize social behavior by providing a basis of legitimate expectations. $^{12}$

The first two prongs are irrelevant: downward mobility frequently stems from legislative decisions made in good faith that treat similar cases similarly. Meanwhile, even if the prohibition on retroactivity protects those who suffer losses from institutional changes, Paul misinterprets that prohibition. Rawls requires only that retroactive criminal laws be used sparingly, and does not prohibit the retroactivity of civil legislation. ${ }^{13}$ A proposal like GASOLINE TAXES or a direct increase in property taxes, though it may seriously set back a landowner's interests, does not violate that landowner's basic liberties.

\footnotetext{
10 Ibid., p. 637.

11 Contrary to ibid., pp. 637-643. Buchanan, "Distributive Justice and Legitimate Expectations," 422, agrees with me that the "rule of law itself appears too lean to provide what is required" for the protection of legitimate expectations.

12 Ellen Frankel Paul, “The Just Takings Issue,” Environmental Ethics 3 (1981): 309-328, at p. 326.

13 Rawls, A Theory of Justice, 209. Christopher Bertram similarly worries that Rawlsian justice will conflict with the "norm of prospectivity," though Bertram-like me and unlike Paul—ultimately prioritizes justice over prospectivity. Bertram, "The Problem of Rawlsian Transition," posting to Crooked Timber, Aug. 7, 2012, http://crookedtimber.org/2012/08/07/the-problem-of-rawlsian-transition/.
} 
Paul likewise misconstrues the idea of justice as regularity, which prohibits invidious bias against individuals or groups as well as individual corruption. ${ }^{14}$ Although Rawlsian justice as regularity "supports and secures legitimate expectations," such expectations must be consistent with the principles of justice, including the difference principle. ${ }^{15}$ The rule of law principle does not elevate the protection of expectations simpliciter-as opposed to legitimate expectations- to the level of a basic liberty. Although Rawls flirts with the idea of endorsing some broader substantive protection of good-faith - rather than objectively legitimateexpectations as part of justice as regularity, he ultimately treats achieving just social institutions as more important than protecting individual expectations. ${ }^{16}$

A further reason to doubt that the rule of law protects against downward mobility derives from the requirement that laws be democratically justified by public reasons. In a Rawlsian society, no individual will simply be expropriated at one stroke by kingly fiat. ${ }^{17}$ Rather, any change must be implemented through a democratic process in which decisions are justified to those affected. The requirement of democratic justification also serves to provide notice to those whose holdings might be affected by a change in law. For instance, before imposing a gasoline tax, a legislature must take up and debate the proposed tax, putting potentially affected interests on notice of the change and giving them the opportunity to argue against or prepare for the effects of potential changes. No reasonably attentive member of society, even if she loses out in the democratic process, will be blindsided by its effects. $^{18}$

\subsubsection{Property}

Some commentators have interpreted Rawls's right to personal property as a purely procedural right that would not justify ensuring that individuals can continue owning and using particular objects, while others interpret the right to personal property as protecting only a decent minimum. ${ }^{19}$ Neither of these interpretations justify special protection against downward mobility.

The right to personal property will only justify protection against downward mobility if interpreted to protect the use and possession of all the personal property one happens to have. Even such a maximal understanding of the right, however,

\footnotetext{
14 Rawls, A Theory of Justice, 207; ibid., 51.

15 On this point, see, for instance, Christine Swanton, "Is the Difference Principle a Principle of Justice?" Mind 90 (1981): 415-421, at p. 418.

16 Ibid. at 51-52.

17 See, for example, Rawls, A Theory of Justice, at 241. I thank Samuel Freeman for helping me to see this point.

18 On this point, see also Jeremy Waldron, The Rule of Law and The Measure of Property (Cambridge: Cambridge University Press, 2012), p. 36-41.

19 For the procedural interpretation, see H.L.A. Hart, "Rawls on Liberty and its Priority," University of Chicago Law Review 40 (1973): 534-555, at p. 540; Jeremy Waldron, "Nozick and Locke: Filling the Space of Rights," Social Philosophy and Policy 22 (2005): 81-110, at p. 84; for the minimal interpretation, see Samuel Freeman, "Capitalism in the Classical and High Liberal Traditions," Social Philosophy and Policy 28 (2011): 19-55, at p. 3.
} 
cannot justify protecting individuals against downward mobility with respect to future income or consumption. Even if expectations of continued employment or receipt of benefits can constitute a sort of property, they do not constitute personal property whose loss would undermine individuals' independence and integrity.

Nor would even the most expansive understanding of Rawlsian personal property protect expectations of receiving income from its use or rental. ${ }^{20}$ There is no personal property right to sell coal that one mines, for instance, even if the coal comes from one's own back yard. Even a maximally broad Rawlsian right to personal property protects only the use and possession of personal property-it does not create an ironclad entitlement to all fruits of that use of personal property. Such a distinction between personal property and its fruits does not rest on any mysterious distinction between productive property and other property, but rather on the familiar distinction between a right to possess something and a right to the proceeds of that thing's use.

\subsection{Fair equality of opportunity}

Rawls's concept of fair equality of opportunity requires "not merely that public offices and social positions be open in the formal sense, but that all should have a fair chance to attain them," where the content of a "fair chance" involves there being "roughly the same prospects of culture and achievement for those similarly motivated and endowed." 21 This idea might be employed to justify special protection against downward mobility. Imagine, for instance, that Automated TRUCKING worsens the job prospects of a truck driver compared to those of an equally motivated and endowed train operator. Protecting the truck driver against downward mobility - for instance, via special hiring preferences for truck driversmay seem consistent with and even required by fair equality of opportunity.

There are two problems with this argument. First, many interpret Rawlsian fair equality of opportunity as only requiring a "moment of equal opportunity" after which individuals' opportunities may diverge. ${ }^{22}$ On this interpretation, as long as the two drivers' prospects were equal at the moment of equal opportunity, differences in opportunity later on do not violate fair equality of opportunity. Second, special protection against downward mobility, even though it situates the truck driver and train operator similarly, gives the recently unemployed truck driver a difficult-to-justify advantage over others who are similarly motivated and endowed, such as immigrants, recent graduates, and those currently in lower-paid positions.

Fair equality of opportunity may also appear to justify special protection against downward mobility on the basis that the talents and skills that current workers

\footnotetext{
${ }^{20}$ Contrary to James W. Nickel, "Economic Liberties," in The Idea of Political Liberalism: Essays on Rawls, eds. Victoria Davion and Clark Wolf (Lanham: Rowman and Littlefield, 2000): 155-175, at p. 166.

21 Rawls, Justice as Fairness, pp. 43-44.

22 See the discussion in Clare Chambers, "Each Outcome Is Another Opportunity: Problems with the Moment of Equal Opportunity," Politics, Philosophy, and Economics 8 (2009): 374-400.
} 
acquired in the course of employment support giving them preference for positions that would use those talents. Rawls observes that "the reasons for requiring open positions are not solely, or even primarily, those of efficiency," but rather that, without fair equality of opportunity, some people would be "debarred from experiencing the realization of self which comes from a skillful and devoted exercise of social duties" and "would be deprived of one of the main forms of human good." 23 Such considerations might seem, for instance, to support funding job retraining programs for the recently unemployed rather than funding programs - such as elementary education - that serve the not-yet-employed.

However, current workers' interest in self-realization cannot justify protecting them against downward mobility at the expense of those who are seeking to begin their involvement in social cooperation. Doing so would violate Rawls's admonition that social institutions should not ask already disadvantaged individuals "to accept still lower prospects of life for the sake of others." 24

As such, although our interest in self-realization helps justify the fair equality of opportunity principle, that principle - as an equality principle-prioritizes giving each person equal access to self-realization over helping the already self-realized become even more so. Though the fair equality of opportunity principle might support state-sponsored efforts to ensure each citizen access to some form of gainful employment, it cannot support efforts to ensure that workers currently occupying particular positions remain in those positions over time.

A related attempt to justify special treatment appeals to Rawls's idea that society constitutes a "system of cooperation." This argument makes the case that individuals are entitled to their present jobs, because their jobs are the way they participate in the system of cooperative activity - one's job might be regarded as one's "place in the cooperative scheme." 25 This objection, however, conflates the (correct) claim that each person is entitled to some place in the cooperative scheme with the (mistaken) one that each person is entitled to maintain the same place in the cooperative scheme over time. Fair equality of opportunity justifies efforts to combat unemployment, which cuts some individuals off entirely from participation in the scheme of social production, even if allowing higher rates of unemployment would increase the consumption enjoyed by the worst-off members of society. ${ }^{26}$ Combatting unemployment, however, does not require maintaining individuals in their current positions; it only requires that each person be afforded an opportunity to contribute in some way.

\footnotetext{
23 Rawls, A Theory of Justice, p. 73.

24 Ibid., p. 155.

25 Rawls, A Theory of Justice, p. 410.

26 Cf. Robert S. Taylor, "Self-Realization and the Priority of Fair Equality of Opportunity," Journal of Moral Philosophy 1.3 (2004): 333-347, at p. 338.
} 


\subsection{The difference principle}

Downward mobility would clearly violate the difference principle if it directly worsened the worst-off positions in society. Buchanan attempts to justify efforts to prevent downward mobility on this basis:

[T] he prospects of the worst off include their prospects of ascending to higher positions, of enjoying the benefits of those positions, and of being able to continue to enjoy those benefits. Maximizing their expectations, then, will require taking into account the stability of institutional arrangements, since liability to future disruptions decreases their present expectations, other things being equal. ${ }^{27}$

\subsubsection{Direct effects}

Downward mobility would violate the difference principle if it directly worsened the worst position with no compensating indirect effects. Austerity policies that lower the income of individuals occupying the worst positions in society without indirectly compensating for that lowering, for instance, clearly violate the difference principle. However, downward mobility plays no essential part in this violation: the aftermath of a change that worsens the position of the worst-off is no more objectionable than the failure to remedy an equally bad and easily remediable status quo.

In later work, Rawls further clarifies that "the least advantaged are by definition those who are born into and who remain in that group throughout their life." 28 This definition of the least advantaged undermines Buchanan's claim that the worst off benefit from policies that protect against downward mobility. Because the least advantaged group comprises only individuals who never move up into a higher group, that group will never directly benefit from policies that protect those who have risen against dropping back down. While the least advantaged have reason to reject a policy that irrationally or arbitrarily makes individual holdings insecure, they have nothing to lose, and much to gain, from an approach that regards protection against downward mobility as subordinate to improving the holdings of the least advantaged.

\subsubsection{Indirect effects}

More interesting are policies that impose downward mobility on some better-off individuals while having neutral or even positive direct effects on the worst position. Examples might include Inflation and Physician Payments, which raise wages and lower health care costs even while reducing the economic position of physicians and creditors. Determining the compatibility of such changes with the

\footnotetext{
27 Buchanan, "Distributive Justice and Legitimate Expectations," 423-424.

${ }^{28}$ John Rawls, Collected Papers, ed. Samuel Freeman (Cambridge: Harvard University Press, 2001), p. 364 .
} 
difference principle requires assessing their indirect effects on the social and economic position of the worst-off group in society. Buchanan believes that the difference principle could protection against downward mobility for the better-off because of the indirect benefits of doing so for the worst-off:

[T]he knowledge that institutional arrangements were liable to revision at any time, as a result of direct application of the difference principle, might itself undermine individual security to such an extent that expectations in general, including the expectations of the worst off, were diminished. ${ }^{29}$

Assessing the indirect benefits about which Buchanan speculates would require an empirical, social-scientific investigation that is beyond our scope here. However, it is worth considering what the upshots of such social science would be. Social science can help us move from normative ideals, such as the difference principle, to policy conclusions in two ways. First, it can determine whether the possibility of downward mobility truly does exert a chilling effect on the choices of the better-off. Even in a world where social and legal arrangements were ironclad and unchanging, individual expectations would remain pervasively vulnerable to other sources of disappointment. For instance, after taking out a loan, a surgeon might suffer a disability or acquire caregiving responsibilities that make a career in surgery impossible. Yet the possibility of these disruptions does not dissuade individuals from pursuing careers in surgery; it is therefore not obvious that disruptions caused by institutional changes will do so.

Second, social science can tell us about the causal pathways by which insecure expectations for the better-off translate into worse circumstances for the worst-off. Such information can help in normatively assessing who is culpable for the worsened situation of the worst-off. For instance, if the least advantaged are suffering because of a policy instituted that frequently seizes surgeons' cars without warning in order to transfer the proceeds to the least advantaged, the policy would be culpable-surgeons cannot help the fact that they need reliable transportation to do their jobs effectively. In contrast, if the least advantaged are suffering because surgeons refuse to work unless guaranteed that their pay will remain the same, surgeons, rather than the policy, are culpable, because surgeons do not require the maintenance of their current economic status in order to do their jobs. There is a well-developed literature that attempts to identify when workers' claims to economic incentives are objectionable. ${ }^{30}$ Demands that institutional arrangements not be changed raise similar issues to demands for wage incentives, and may be amenable to a similar analysis. ${ }^{31}$

Most importantly, even where the difference principle, because of indirect effects, justifies special protection against downward mobility, this special

\footnotetext{
${ }^{29}$ Buchanan, "Distributive Justice and Legitimate Expectations," 423-424.

30 For example, Joshua Cohen, "Taking People as They Are?" Philosophy \& Public Affairs 30.4 (2001): $363-386$.

31 Cohen describes the aim of preserving one's current privileges in order to maintain social distance between oneself and those worse off as much more objectionable than a simple desire to gain in absolute terms. Ibid. at pp. 369-371.
} 
protection is not provided for the sake of those it protects, but the sake of the worst off. Were social science to conclude that protections against downward mobility did not optimize the position of the worst-off, the case for these protections would collapse. As such, any effort to ground protection against downward mobility in the difference principle differs fundamentally from a strategy that appeals to the basic liberties or fair equality of opportunity. The difference principle will never regard the economic status of the better-off as inviolable; at most, it will protect their economic status insofar as such protection happens to further the interests of the worst-off.

\section{Downward mobility and Rawlsian concepts}

\subsection{Legitimate expectations}

Nien-hê Hsieh interprets Rawls's concept of legitimate expectations as justifying special protection for those who experience downward mobility due to social change. He does so via the example I called Physician Payments:

Betty is a medical student in the United States who borrows $\$ 100,000$ to cover the cost of her medical training with the expectation that she will be able to repay the loan once she has entered into private practice as a surgeon. As a surgeon she is legally entitled to receive the salary that will allow her to repay the loan, but at the time of taking out the loan she is not legally entitled to the prospect of becoming a surgeon. Now suppose that the government institutes a national health care system in which the amount that doctors can earn is substantially diminished relative to what they did prior to the change in the health care system. ${ }^{32}$

Hsieh asserts that "there is a sense in which fairness demands that Betty's expectation, at least with respect to her ability to repay the loan, be fulfilled," and that "[h]er expectation of being able to repay the loan can be understood as a legitimate expectation, even though she was never legally entitled to the prospect of becoming a surgeon." 33

Betty's case may arouse our sympathy. But I disagree with Hsieh that considerations of fairness entitle Betty to have her expectations met, because her expectations, though strongly held, are not legitimate. Legitimate expectations cannot arise purely through custom. ${ }^{34}$ The new health care system must be consistent with the basic liberties and fair equality of opportunity, and must maximize the position of the worst off. It is easy to see how the new health care system Hsieh describes would be consistent with the difference principle: imagine

\footnotetext{
32 Hsieh, "Moral Desert, Fairness and Legitimate Expectations in the Market," p. 103.

33 Ibid., p. 103. Hsieh also states, at p. 104, that Betty's "expectations are legitimate... because they arise within the context of following institutionally specified rules.".

34 See Rawls, A Theory of Justice, p. 252.
} 
that, for instance, the money saved by paying physicians less would permit greater access to medicines or lower out-of-pocket costs for the most disadvantaged patients. Refusing to implement the new system because of its effects on Betty's expectations would impose greater costs on the worst-off members of society, and the government would therefore violate the difference principle-and hence act unjustly-were it to fulfill her expectations. Betty's expectations thus cannot be legitimate.

Approaching Betty's case through the lens of contract theory helps clarify why her expectations lack normative force. When private citizens contract with one another, they accept that certain "escape conditions" established in contract lawsuch as mistakes of fact or law, impossibility or impracticability of performance, or substantive unconscionability - could release the parties from their legal duties to perform. Analogously, an individual receiving a promise from the state in a Rawlsian society cannot expect that the promise be kept come what may. Instead, a Rawlsian state's contracts with private parties include a moral, rather than legal, "escape condition": there is no obligation to fulfill the expectations of private parties, even expectations the state has encouraged, in cases where doing so would be inconsistent with a principle of justice. A system of rules must be just in order for the expectations it authorizes to be legitimate. ${ }^{35}$

The idea that rights or duties contain an "escape condition" is by no means unique to Rawls's theory. Another example is what Robert Nozick calls the "Lockean proviso," which prohibits anyone from appropriating property in a way that does not leave "enough and as good...in common for others." 36 As Nozick observes, the Lockean proviso will sometimes disrupt property-holders' expectations: even if a water-hole owner could not have foreseen all other water-holes drying up, his expectation of unlimited profits from the water hole goes beyond what his property right can support. ${ }^{37}$

Because of the structure of Rawls's theory of justice, in particular that of the difference principle, an escape condition will much more frequently come into play in Rawls's theory than in Nozick's. The Lockean proviso is a satisficing principle: it merely requires parties to a contract to leave enough for others. In contrast, the difference principle - though it plays a structurally parallel role to the Lockean proviso-is an optimizing principle: it requires that the worst position be made as good as possible. Because it is an optimizing principle, the difference principle typically leaves no spare resources for the fulfillment of contracts.

A Rawlsian state's contractual commitments will therefore only be relevant when the principles of justice are neutral between two alternatives. If fulfilling Betty's expectations would have no net impact on the worst-off position, the state should fulfill her expectations for her sake. But if fulfilling them would hurt the worst-off,

\footnotetext{
35 Ibid., p. 207.

36 Robert Nozick, Anarchy, State, and Utopia (New York: Basic Books, 1974), pp. 175-176.

37 Ibid., p. 180.
} 
the state should not fulfill her expectations. ${ }^{38}$ And if fulfilling them would lead to a better position for the worst off, the state should fulfill them, but for the sake of the worst-off rather than for her sake. Perhaps Betty's claims could be given slightly more purchase by also treating them as relevant in situations where we are radically uncertain which policies will optimize the worst position, or where we regard two policies as on a par-rather than identical-with respect to their effects on the worst position. But I doubt such a revision would extend her claims' reach to many more cases.

What I have said is fully consistent with our regretting that Betty's expectations go unfulfilled, and even with our apologizing to Betty for her having to bear the brunt of what we do. But we can regret an unavoidable injury, and apologize for it, while recognizing that justice requires it. This would be clear in a case where fulfilling Betty's expectations required violating someone's bodily integrity or depriving them of their right to vote-in such a case, though we might regret having to upset Betty's expectations, we would not treat Betty's expectations as overriding those important interests. Indeed, if Betty possesses the sense of justice that Rawls posits the citizens of a just Rawlsian state would, she would not press her claims when their fulfillment would be inconsistent with the fulfillment of principles of justice. She would regard demanding that she be paid what she had originally expected as analogous to demanding the enforcement of an unconscionable contract. Even if the contract might have seemed unexceptional when made, she recognizes that the needs of the worst-off now override the fulfillment of her expectations.

At bottom, Hsieh's and others' invocation of legitimate expectations as limits on the pursuit of justice reflects an implicit rejection of the maximizing force of the difference principle, and potentially the fair equality of opportunity principle as well, in favor of similar satisficing principles: a "decent minimum" or "sufficiency of opportunity" principle. If fulfilling Betty's expectations meant violating someone's bodily integrity or abrogating her right to vote, the plausibility of the escape condition would be obvious. But that fulfilling Betty's expectations would fail to maximize the worst position, or would prevent the opportunities of those similarly talented and motivated from being truly equal, may not motivate the escape condition's plausibility as fully.

Rawls discusses weaker distributive principles such as the decent minimum principle in his later work, where he suggests that the satisficing analogues of the difference principle and fair equality of opportunity are constitutional essentials, whereas his original principles themselves—while still principles of justice-are not constitutional essentials:

While some principle of opportunity is a constitutional essential-for example, a principle requiring an open society, one with careers open to talents (to use the eighteenth-century phrase)—fair equality of opportunity

\footnotetext{
38 See Rawls, A Theory of Justice, 68 ("A scheme is unjust when the higher expectations, one or more of them, are excessive. If these expectations were decreased, the situation of the least favored would be improved.").
} 
requires more than that, and is not counted a constitutional essential. Similarly, although a social minimum providing for the basic needs of all citizens is also a constitutional essential, the difference principle is more demanding and is not so regarded. ${ }^{39}$

In a society that adopts the satisficing alternative to Rawls's original principles (the careers-open-to-talents principle of opportunity, or the decent minimum principle of distributive justice), the state's contractual commitments will more often justify compensation rather than mere apology. However-as the earlier example of the Lockean proviso indicates - these alternative principles will still sometimes conflict with contractual duties.

Buchanan agrees with me that, within Rawlsian justice, principles of justice constrain what counts as a legitimate expectation. But, unlike me, Buchanan regards this as objectionably demanding:

[A]s previously just Rawlsian basic structures become unjust instantaneously in the light of new information about how to maximize the benefit of the worst off, so previously legitimate Rawlsian expectations lose their legitimacy just as instantaneously. ${ }^{40}$

Buchanan then considers two examples where expectations lose legitimacyincluding one, almost identical to Hsieh's, that involves the disrupted expectations of healthcare workers - and goes on to assert that "the strongest grievance of a person who is disadvantaged by such institutional changes is not simply that his wants have been thwarted. His functioning as a rational planner and executor of long-range plans has been undercut by his society's attempts to continue to satisfy the difference principle." 41

Buchanan, however, simply describes prevailing expectations as "legitimate" without explaining why these expectations are normatively legitimate, rather than merely strongly held, and without justifying his claim that disrupted expectations render planning impossible. An individual in a Rawlsian society must be prepared to adjust her plans in response to the demands of justice: such willingness to adjust one's plans is part of having a sense of justice. Functioning as a rational planner does not plausibly require the ability to perfectly predict one's future occupation and holdings, or even to do so within a narrow range. ${ }^{42}$ Although a just Rawlsian society offers no assurance that individuals will enjoy (or suffer) their current material position come what may, it provides the more normatively important assurances of equal basic liberties, fair equality of opportunity to compete for

\footnotetext{
39 Rawls, Justice as Fairness, pp. 47-48.

40 Buchanan, "Distributive Justice and Legitimate Expectations," p. 421.

41 Ibid. See also the similar claim in Joel Feinberg, "Rawls and Intuitionism," in Norman Daniels, Reading Rawls (Stanford: Stanford University Press, 1989), 117. Feinberg complains that "[t]o change the rules in the middle of the game, even when those rules were not altogether fair, will disappoint the honest expectations of those whose prior commitments and life plans were made in genuine reliance on the continuance of the old rules.".

42 Andrei Marmor, “The Rule of Law and Its Limits," Law and Philosophy 23 (2004): 1-42, at p. 23.
} 
positions of advantage, and a social minimum of primary goods. Such assurances are amply sufficient for the pursuit of a rational plan of life.

Indeed, institutional reforms designed to better realize justice can not only be consistent with rational planning, but also enrich the goodness of a life. Ronald Dworkin suggests what he calls the "challenge model" of a good life, on which living a good life requires appropriately grappling with the challenges of living well, rather than amassing some sum of goods or pleasures. On the challenge model, "a good life is a life suited to the circumstances that justice requires," which entails that life is enriched rather than constrained by the restriction that one may use only the resources that one can justly claim:

It would be bizarre to declare, as our considered moral judgment, that it is appropriate for people each to have a fair share of resources, defined in some particular way, and not also to think, in making an ethical judgment about what circumstances we should treat as appropriate in deciding what life would be good for us, that fair circumstances, so defined, are the appropriate ones.... We must set the resource parameters of a life well lived, so far as we can, so that these respect our sense of justice. ${ }^{43}$

Dworkin goes on to suggest that someone's life goes worse, rather than better, to the extent that he is better-off economically than justice allows. This factor could conceivably be counterbalanced by others: for Dworkin, unlike Rawls, justice is not prior to goodness. Nor is it an inescapable requirement of a good life. Rather, justice rather is an important, but overridable, constituent of a good life. Still, it would take an extraordinary circumstance for the goodness of enjoying great wealth to outweigh the badness of a life of injustice.

\subsection{Life planning and the Aristotelian principle}

Where the realization of principles of justice conflicts with individuals' particular plans of life, Rawls's account requires that the plans and not the principles give way. Plans of life fall within the theory of the good, not the theory of the right, and a Rawlsian society prioritizes the right (justice) over the good (life plans). So long as an individual remains able to pursue some rational plan of life after her original expectations are disrupted, her expectations do not restrict a Rawlsian society's efforts in pursuit of justice. Furthermore, this conclusion need not be as burdensome as it may initially appear.

In a Rawlsian society, "each individual has a rational plan of life," 44 and such plans enable individuals to achieve happy lives. ${ }^{45}$ Social and institutional change may threaten individuals' ability to carry plans through. While institutional change can threaten good fortune, it can also free individuals from bad fortune. But Rawls-in contrast with the priority he gives to raising the worst-off up in his theory

\footnotetext{
43 Ronald Dworkin, Sovereign Virtue (Cambridge: Harvard University Press, 2002), p. 265.

44 Rawls, A Theory of Justice, p. 80.

45 Ibid., p. 359.
} 
of the right - suggests that the preservation or increase of good fortune matters as much to a successful life than the avoidance of bad fortune. ${ }^{46}$ According to the Aristotelian Principle, "other things equal, human beings enjoy the exercise of their realized capacities (their innate or trained abilities), and this enjoyment increases the more the capacity is realized, or the greater its complexity." ${ }^{47}$ This principle will tend to make downward mobility more painful, because once one has enjoyed the pleasures of exercising superior skill, the exercise of more basic skills will seem less satisfying.

However, life plans are subordinate to the realization of justice. Rightness (the fulfillment of principles of justice) has priority over goodness (life plans): "Our way of life, whatever our particular circumstances, must always conform to the principles of justice that are arrived at independently." 48 While plans of life may be relevant in cases where the principles of justice are in equipoise between two alternatives, just as expectations can be relevant in such cases, the principles of justice override the plans of individuals whenever the two conflict.

Though downward mobility may temporarily frustrate individuals, other remarks of Rawls's suggest that downward mobility is not as onerous as it might appear, because individuals are capable of adapting to institutional change:

They do not think of themselves as inevitably bound to, or as identical with, the pursuit of any particular complex of fundamental interests that they may have at any given time, although they want the right to advance such interests (provided they are admissible). Rather, free persons conceive of themselves as beings who can revise and alter their final ends and who give first priority to preserving their liberty in these matters. ${ }^{49}$

Rather than choosing to pursue inflexible plans that require the accumulation of specific, costly material goods, individuals in a Rawlsian society will pursue more malleable plans that incorporate values compatible with the realization of principles of justice-they will seek, for instance, "meaningful work and social cooperation," rather than developing attachments to lives as highly paid surgeons or bankers. ${ }^{50}$ Even if swings up and down upset individuals' plans, such swings are not properly described as catastrophic because they do not deprive individuals of basic liberties, equality of opportunity, or access to primary social goods. Indeed, as the discussion of Dworkin's “challenge model" suggests, dealing constructively with the challenge that social and economic change presents may be part of what makes a life good.

Individuals in a Rawlsian society will also choose plans that keep options open and allow for long-term revision. Those who can only pursue a single plan of life

\footnotetext{
46 Ibid., pp. 369-370.

47 Ibid., p. 374.

48 Ibid., p. 394-395.

49 Ibid., p. 131-132.

50 Ibid., p. 373.
} 
will be exceedingly rare-though not entirely absent. ${ }^{51}$ Furthermore, individuals should be aware not only that their personal plans may require revision, but also that social institutions may change in order to better realize principles of justice. (The possibility of institutional revision is clear from the opening page of $A$ Theory of Justice, where Rawls asserts that "laws and institutions no matter how efficient and well-arranged must be reformed or abolished if they are unjust." 52 ).

Recognizing the priority of right over good also indicates that a Rawlsian society will limit certain forms of institutional change, though it will do so for the sake of justice rather than for the sake of preventing downward mobility. For instance, if science suggested that a technical innovation-such as a new method of extracting fossil fuels-will likely lead to long-term economic losses, a Rawlsian society would resist that innovation, though for the sake of society as a whole rather than for the sake of protecting those whose jobs that innovation would threaten. A Rawlsian society has no intrinsic bias toward change or stability-it neither preserves the status quo nor praises its disruption-but only a bias toward justice.

Ultimately, it is difficult to believe that institutional change undermines workers' status as rational agents. Rather, individuals can form plans of life compatible with a changing economy, secure in the knowledge that they enjoy basic liberties, equality of opportunity, and a decent social minimum.

\subsection{Distribution, allocation, and pure procedural justice}

Rawls defines allocative justice, which is is inappropriate for goods produced via social cooperation, as the "problem of how a given bundle of commodities is to be distributed, or allocated, among various individuals whose particular needs, desires, and preferences are known to us, and who have not cooperated in any way to produce these commodities." 53 In contrast, distributive justice focuses on background institutions and does not directly provide answers to questions about which individuals should hold which resources. It might therefore seem that distributive justice prohibits the imposition of downward mobility that disturbs individual holdings in service of justice.

However, although distributive justice precludes the direct employment of Rawlsian principles of justice to determine which individuals should receive resources in specific situations, legislators clearly are supposed to apply Rawlsian principles when making policy choices about free trade, responses to climate change, or taxation. ${ }^{54}$ Applying the difference principle, for example, will entail the design of social institutions that inevitably disturb individual holdings.

Understanding this defuses David Schmidtz's complaint that the need for "adjustments in the basic structure" vitiates Rawls's claim that the difference principle does not require continuous and capricious interference with private

\footnotetext{
51 Ibid., p. 380.

52 Ibid., p. 3.

53 Rawls, Justice as Fairness, p. 50.

54 Rawls, A Theory of Justice, p. 175.
} 
transactions. ${ }^{55}$ While Schmidtz is right that a Rawlsian society would likely indeed engage in continuous interference with people's transactions, at least if we follow Schmidtz in understanding any societal decision that affects the value of individual holdings as an interference, it would not engage in capricious interference. To see why, return to Inflation. A Rawlsian society could, and indeed likely would, adopt a monetary policy, which involves taking actions that affect rates of inflation as well as the exchange rate of its national currency. The worth of individuals' holdings would then be subject to continuous adjustment as inflation and exchange rates vary over time, and these adjustments would be justified-and consistent with pure procedural justice-insofar as they optimally realized the principles of justice. ${ }^{56}$

INFLATION indicates that continuous interference is not obviously objectionable as long as it is not capricious interference. And a Rawlsian constitutional democracy would base its fiscal policy not on the caprice of unaccountable administrators but on legislative, executive, and judicial decisions that must in turn be justified in a democratic process by appeal to public reasons and principles of justice. A Rawlsian society's implementation of monetary policy, for instance, would not be carried out on an allocative, transaction-by-transaction basis, but rather at the level of the basic structure, which ensures that individuals are subject to the same laws and are free from arbitrary and unaccountable power. Indeed, Rawls argues that efforts to protect particular individuals and groups would hamper, rather than advance, the achievement of justice. ${ }^{57}$

Pure procedural justice, as Rawls understands it, requires us to focus on the benefits and burdens of institutional change from the point of view of society in general, rather than considering the specific impacts on each individual the policy burdens or benefits. While individual impacts matter when ensuring that policies do not violate basic liberties, if some policy is broadly fair-if it best accords with fair equality of opportunity, the difference principle, and the basic liberties- the burdens it imposes on specific individuals cannot justify refusing to adopt that policy or restricting its effects.

Rawlsian justice therefore has adequate resources to answer Schmidtz's concern about " "necessary adjustments' that signal to citizens that their labor is a political football and they are to that extent governed by men, not law." 58 Although policy choices in a Rawlsian democracy may subject individuals to downward mobility, these choices reflect the effects of legitimate laws rather than arbitrariness or caprice.

\footnotetext{
55 David Schmidtz, Elements of Justice (New York: Cambridge, 2005), p. 200.

${ }^{56}$ For different approaches to the reconciliation of redistribution and pure procedural justice, compare Joshua Cohen, "Pluralism and Proceduralism," Chicago-Kent Law Review 69 (1993), 589-618, at p. 597 n. 44, with Jeremy Waldron, "The Rule of Law in Contemporary Liberal Theory," in G.W. Smith (ed.) Liberalism: Rights, Property and Markets (New York: Routledge, 2002), p. 103.

57 Rawls, A Theory of Justice, at p. 76.

58 Schmidtz, Elements of Justice, p. 200.
} 
Hayek advances a different argument based on pure procedural justice, which makes the case that if social arrangements and announced systems of public rules were just in the past, they remain just later on regardless of their consequences. ${ }^{59}$ On this view, rules and institutions that are just when formed never need to prove their ongoing compatibility with justice: rather, they inherit their current justice from their justice at inception. Such an understanding of the justice of rules and institutions would parallel Nozick's view that distributions are just in virtue of their history rather than in virtue of how they distribute resources among individuals. ${ }^{60}$

This understanding of justice not only appears implausibly rigid, but fails as an interpretation of Rawls's view. In A Theory of Justice, Rawls explicitly asserts that adjustments are required even under ideal circumstances. ${ }^{61}$ Rawls believes that a well-ordered society can be stable even while updating its basic structure and public rules in order to maintain or better realize the principles of justice in light of newly discovered facts and changing circumstances. ${ }^{62}$ A rule's being initially just, for Rawls, does not render it eternally just. As such, in a Rawlsian society, individuals should form their social and economic expectations with the knowledge that the currently prevailing rules are subject to adjustment in service of justice. A society in which the basic structure never required adjustment would not be more just than a Rawlsian ideal society. Rather, it would be beyond justice, and outside the scope of Rawls's discussion.

\section{Conclusion}

I have argued that, in an ideal Rawlsian society, individuals would willingly accept the more valuable guarantee that they will be protected by the principles of justice in exchange for sacrificing the less valuable guarantee that their holdings will not be disturbed by downward mobility. This argument suggests a direction for further research, focused on how downward mobility should be addressed in a nonideal society where the principles of justice are not fully honored. ${ }^{63}$ Though Rawls explicitly states that concerns about disrupted expectations do not justify resisting a move from nonideal to ideal circumstances, ${ }^{64}$ the treatment of downward mobility under circumstances that will remain nonideal regardless of how downward mobility is addressed poses more complex questions.

\footnotetext{
59 See Waldron, "The Rule of Law in Contemporary Liberal Theory," 103, and more generally Andrew Lister, "The 'Mirage' of Social Justice: Hayek Against (and for) Rawls," Critical Review 25 (2013): 409-444.

60 Nozick, Anarchy, State, and Utopia, 150-51.

61 Rawls, A Theory of Justice, p. 285.

62 Ibid., p. 401.

63 Cf. Dworkin, Sovereign Virtue, p. 265 ("Once we accept that the best life means a life responding well to the right circumstances, and that the right circumstances are circumstances of justice, we become aware of how difficult it is to lead anything like the right life when circumstances are far from just.").

64 Rawls, Collected Papers, p. 251.
} 
Where social change cannot bring about justice but can only achieve an improvement in nonideal circumstances, some argue that individuals may allowably regard the burdens of downward mobility as counting against, though not invariably prohibiting, changes that would make social arrangements more just. ${ }^{65}$ Rawls himself observes that principles of justice may not apply in the same way-or at all-in nonideal contexts, which indicates that the balance between Rawlsian principles and the prevention of downward mobility might, in nonideal contexts, tilt toward the latter. ${ }^{66}$ On the other hand, under nonideal circumstances, individuals frequently owe the holdings they hope to protect to their own, or others', failure to comply with the principles of justice. ${ }^{67}$ For this reason, Rawls suggests elsewhere that the imposition of social change may be acceptable under nonideal circumstances if it moves society toward more just (though still nonideal) arrangements that improve conditions for the least advantaged. ${ }^{68}$ Ultimately, because nonideal conditions weaken individuals' claims to their current circumstances while also weakening the guarantees they would receive after social change, assessing the proper treatment of downward mobility under nonideal conditions requires further analysis. This project's discussion of downward mobility within ideal theory represents one starting point for such analysis, though there is no straightforward algorithm for how movement away from ideal theory affects the applicability of arguments originally developed in an ideal-theory context.

In sum, an ideal Rawlsian society countenances social and economic change, even change that imposes downward mobility on individuals, when that change furthers the achievement of justice. However, that Rawls's theory descriptively does not protect against downward mobility may seem like a reason to amend Rawlsian justice to add an additional principle that supports shielding individuals from downward mobility. ${ }^{69}$ My project, however, has been to argue not only that Rawlsian justice excludes special protection against downward mobility, but also that its choice not to do so is normatively attractive. I conclude by reiterating the latter point. Beliefs that Rawlsian justice must be amended to protect individuals against downward mobility stem ultimately from two misplaced fears-the fears that downward mobility will be imposed through despotism and lead to destitution. But Rawls's principles of justice are amply sufficient to achieve a just society; an additional principle protecting against downward mobility would prove counterproductive and excessively conservative.

\footnotetext{
65 Marcus Arvan, "First Steps Toward a Non-Ideal Theory of Justice," Ethics and Global Politics 7 (2014): 95-117, at pp. 104-107; Leslie Pickering Francis, "Age Rationing Under Conditions of Injustice," in Rosamond Rhodes et al. eds., Medicine and Social Justice (Oxford: Oxford University Press, 2002), p. 274.

66 Rawls, A Theory of Justice, pp. 215-216. I am grateful to an anonymous referee for this reference and for prompting me to attend more closely to the case of downward mobility within ideal theory.

67 See Christopher Bertram, “Cosmopolitanism and Inequality,” Res Publica 12 (2006): 327-336, at p. 334.

68 See Rawls, A Theory of Justice, p. 218.

69 Andreas Føllesdal, "Union Citizenship: Unpacking the Beast of Burden," Law and Philosophy 20 (2001), 329.
} 
The fear of despotism equates downward mobility with change imposed for reasons that are at best arbitrary and at worst self-serving and corrupt. ${ }^{70}$ But a Rawlsian constitutional democracy already has safeguards that prevent the imposition of policies for arbitrary, self-serving, or corrupt reasons. Further, to the extent that classical liberal critics like Schmidtz are concerned that these safeguards are insufficient to forestall the improper deployment of power, focusing concern on policies that impose downward mobility seems misguided. Such a focus would leave those attempting to form new plans at the mercy of arbitrary regulations while those with longstanding, settled expectations are kept secure against abuses of power.

Meanwhile, the fear of destitution equates downward mobility with a total dismantling of self-respect and even of rational agency. ${ }^{71}$ But a Rawlsian society provides ample opportunity for rational planning. Individuals who experience downward mobility can stably and legitimately expect to enjoy a decent social minimum, fair equality of opportunity, and equal basic liberties as they revise their plans and projects in light of new circumstances. Such a society is far preferable to one that exhaustively protects existing plans against any disruption while leaving others without sufficient liberties, opportunities, and resources to even begin making-let alone acting on-plans of their own.

Acknowledgements I am grateful to Debra Satz, Joshua Cohen, Eamonn Callan, Mark Kelman, Jorah Dannenberg, Collin Anthony, RJ Leland, Samuel Freeman, Nien-hê Hsieh, Shim Reza, and an anonymous referee at Philosophical Studies for written comments and detailed discussion. Thanks also to audiences at the 2012 National Endowment for the Humanities Summer Seminar on Liberty, Equality, and Justice; the 2012 Harvard Graduate Conference in Political Theory; and the 2014 Ethics and Politics, Ancient and Modern workshop at Stanford University.

\section{References}

Arvan, M. (2014). First steps toward a non-ideal theory of justice. Ethics and Global Politics, 7, 95-117. Bertram, C. (2006). Cosmopolitanism and Inequality. Res Publica, 12, 327-336.

Bertram, C. (2012) "The Problem of Rawlsian Transition," posting to Crooked Timber, August 7, 2012. http://crookedtimber.org/2012/08/07/the-problem-of-rawlsian-transition/.

Brown, A. (2012). Rawls, Buchanan, and the legal doctrine of legitimate expectations. Social Theory and Practice, 38, 617-644.

Buchanan, A. (1975). Distributive justice and legitimate expectations. Philosophical Studies, 28, 419-425.

Chambers, C. (2009). Each outcome is another opportunity: Problems with the moment of equal opportunity. Politics, Philosophy, and Economics, 8, 374-400.

Cohen, J. (1993). Pluralism and proceduralism. Chicago-Kent Law Review, 69, 589-618.

Cohen, J. (2001). Taking people as they are? Philosophy \& Public Affairs, 30(4), 363-386.

Cohen, J. (with Seth Resler) (2011). "Occupation as fairness: What John Rawls would make of the occupy movement," Boston Review (Nov. 17, 2011), http://bostonreview.net/joshua-cohen-sethresler-john-rawls-occupy-wall-street.

Dworkin, R. (2002). Sovereign virtue. Cambridge: Harvard University Press.

\footnotetext{
70 Hsieh, "Moral Desert, Fairness and Legitimate Expectations in the Market," 103; Schmidtz, Elements of Justice, 200.

71 Buchanan, "Distributive Justice and Legitimate Expectations," 425, discusses the "stability of legitimate expectations so essential to us as rational agents."
} 
Feinberg, J. (1989). “Rawls and Intuitionism”, in Norman Daniels, Reading Rawls. Stanford: Stanford University Press.

Føllesdal, A. (2001). Union citizenship: Unpacking the beast of burden. Law and Philosophy, 20, 313-343.

Francis, L. P. (2002). Age rationing under conditions of injustice. In R. Rhodes et al. (Eds.), Medicine and social justice. Oxford: Oxford University Press.

Freeman, S. (2011). Capitalism in the classical and high liberal traditions. Social Philosophy and Policy, 28, 19-55.

Hart, H. L. A. (1973). Rawls on liberty and its priority. University of Chicago Law Review, 40, 534-555.

Hayek, F. A. (1976). Law, legislation, and liberty, Vol. 2: The mirage of social justice. Chicago: University of Chicago Press.

Hsieh, N. (2000). Moral desert, fairness and legitimate expectations in the market. Journal of Political Philosophy, 8, 91-114.

James, A. (2012). Fairness in practice. New York: Oxford University Press.

Lister, A. (2013). The 'Mirage' of Social Justice: Hayek Against (and for) Rawls. Critical Review, 25, 409-444.

Marmor, A. (2004). The rule of law and its limits. Law and Philosophy, 23, 1-42.

Mazie, S. (2011) "Rawls on Wall Street," The New York Times (October 21, 2011). http://opinionator. blogs.nytimes.com/2011/10/21/rawls-on-wall-street/.

Meyer, L. H., \& Sanklecha, P. (2011). Individual expectations and climate justice. Analyse \& Kritik, 2, 449-471.

Nozick, R. (1974). Anarchy, state, and utopia. New York: Basic Books.

Paul, E. F. (1981). The just takings issue. Environmental Ethics, 3, 309-328.

Rawls, J. (1999). A theory of justice. Cambridge: Harvard University Press.

Rawls, J. (2001). Collected papers. In S. Freeman (Ed.). Cambridge: Harvard University Press.

Swanton, C. (1981). Is the difference principle a principle of justice? Mind, 90, 415-421.

Taylor, R. S. (2004). Self-realization and the priority of fair equality of opportunity. Journal of Moral Philosophy, 1(3), 333-347.

Waldron, J. (2002). The rule of law in contemporary liberal theory. In G. W. Smith (Ed.), Liberalism: Rights, property and markets. New York: Routledge.

Waldron, J. (2005). Nozick and Locke: Filling the space of rights. Social Philosophy and Policy, 22, 81-110.

Waldron, J. (2012). The rule of law and the measure of property. Cambridge: Cambridge University Press. 